\title{
TRACTOR SAFETY AND WEED CONTROL
}

\author{
By C. J. CROSBIE, Department of Agriculture, Christchurch
}

There have been 169 tractor fatalities in the last 9 years (1949-57 inclusive). In the last 2 years there have been 4 tractor fatalities directly associated with the weed spraying industry and this year at least one serious accident that could easily have resulted in death.

From the five case histories that follow it will be evident that there has been a total disregard for some of the most elementary rules of safe tractor operation. It is felt that those associated with the weed control industry should be conversant with the details of these past mishaps and thus be better able to prevent further cases in the future by bringing to the attention of field operators some of the unsafe practices that have been indulged in in the past.

The details of the 4 fatalities and one serious accident are:

(1) In February 1956 a competent driver was spraying blackberries with an old rubber-tyred tractor with the rear wheels fully extended, pulling a heavy trailer on which was mounted a spraying outfit complete with a 100 gallon tank. He moved the unit down a grassed siding of about 23 degree slope and parked it facing downhill at an angle of 45 degrees across the slope while with a $100 \mathrm{ft}$. hose he sprayed some blackberries below in the bottom of the gully. Finishing, and desiring to move to the top of the slope, he tried to reverse up the hill, but the rear wheels the top of the slope, he tried to reverse up the hill, but the rear wheels tractor in forward gear he engaged the clutch with a jerk and after proceeding $3 \mathrm{ft}$ the trailer overturned taking the tractor with it. The unit did one complete turn to land on its wheels at the bottom of the hill. The driver was killed instantly in the roll over. A witness considered that the cause of the initial tipping was the splashing of the 100 gallons of spray in the tank and the steepness of the hillside.

(2) A week later a tractor driver, who had also been spraying blackberries on a hillside, was found dead 2 to 3 yds. from his upturned tractor. He had been using a tricycle-type tractor with a 44 gallon drum nearly full of spray mounted on the high side of the tractor, a spraying outfit, and a of spray mounted While he was working on a 35 degree hillside, the rear wheel lead of hose. While he was working on a $2 \mathrm{ft} .2 \mathrm{in}$. over a concealed ledge into a cattle track. The tractor rolled upside down and then slewed round, breaking the main frame.

As there were no witnesses, it is not known if he was driving the machine when it rolled; or whether he was working below the unit, when, because of insecure brakes, it moved and rolled on top of him.

The rear wheel tyres were in good order, set at $5 \mathrm{ft}$. 9 in. centres, but no grippers were fitted.

(3) In February 1957 a farmer with a wheeled tractor, a 10 gallon drum and pump on the drawbar, and a hand line and wand was spraying scattered ragwort and had been driving along the edge of a terrace below which ras a 25 -degree slope to a small stream and bog $20 \mathrm{ft}$. below. The slope was in scrub and rough, while the terrace was in pasture and the edge was in scrub and rough, while the terrace was in pasture and the edge
clearly defined. The tractor was driven too close to the edge so that it slid $7 \mathrm{ft}$. down the slope, hit a bump, and rolled over to come to rest upside down partly submerged in the stream. The driver was found pinned under the tractor in $4 \mathrm{ft}$. of water, death being due to drowning.

From the wheel marks it appeared that on one previous occasion the tractor was in danger of slipping over the edge of the terrace.

(4) In March 1957 a farmer borrowed a neighbour's tractor and frontend loader to load some soil on to a trailer. The tractor, which was strange 
to him, had two 44 gallon drums of water on a 2 in. deep steel platform at the rear with no stays to the drums. They were part of a weed spraying outfit and were also used as a counter-balance for the front-end loader.

He was driving a few yards backward and forward each time. His 4year-old son, interested in the new tractor, was running behind and round the machine. He would not allow the child to ride on the tractor and told him to stand by a fence, which the boy did, but he soon began running round again. Finally, because of the danger of backing over the boy the father put him on top of one of the drums.

Later in the course of loading soil he backed the tractor up and, after declutching, it continued to run slowly back. He put it in forward gear and engaged the clutch suddenly. The boy fell off the unit and a drum of water landed on the boy's head causing instantaneous death.

(5). In April 1958 a serious accident occurred when a farmer was spraying gorse on a very steep face with a tractor-driven spray outfit and a trailer to contain the drums of spray.

The tractor was parked on a sloping ledge below the brow of a hill while the steep face below the tractor was sprayed and on completion of the area the farmer attempted to drive the unit back up a 1 in 4 slope to the top. He reached a spot with the front wheels up on top of a ledge and the rear wheels below it. The rear wheels skidded and he stopped. He made two further attempts to drive up the slope, but each time the front wheels started to come up off the ground. On the third attempt the tractor came right over and pinned the operator under it. He suffered several broken ribs and a punctured chest and spent 3 weeks in hospital.

As the tractor reared backward the drawbar pin broke, allowing the trailer to roll back down the slope and thus allowing the tractor to fall back on to clear ground. The mudguards and petrol tank saved him from being crushed to death-he fell between them.

\section{REVIEW OF THE CASES}

It is now generally accepted that the safe upper limit is 20 degree slopes for wheeled tractors and 30 degree slopes for tracked types.

The 3 wheeled tractors that rolled over and killed their drivers while weeds were being sprayed were operating on 23 degrees, 35 degrees, and 25 degrees respectively. Under these circumstances the machines were close to rolling over as soon as they entered on the slope and very little was required to bring them to the point of instability.

The fourth fatality occurred because the machine was mechanically unsafe-the drums were not fixed to the tractor and a sudden jerk caused one of them to tip out of the platform.

The serious accident was caused because the tractor met a near vertical ledge when travelling straight up a moderate slope. Under these circumstances it is not uncommon for the tractor to somersault backward, and a number of tractor drivers have been killed in this way in recent years. Even a tracklaying tractor will somersault backward if, when travelling straight uphill, it meets a near vertical bank about $2 \mathrm{ft}$. high.

\section{THE SOLUTION}

To help reduce the toll of tractor accidents spraying firms are asked to bring the above case histories to the notice of their clients as opportunity offers and in particular:

Firms manufacturing spraying equipment are asked to add a paragraph to the instruction manual asking that the spray drums be tied down to or firmly fixed to the tractor.

Manufacturing firms and all distributors selling spray equipment should 
make sure that their clients purchase spray hoses of adequate length for their respective properties. The interest on the capital outlay required to purchase an extra 2 to $300 \mathrm{ft}$. of hose can be regarded as a small life insurance policy. It should not be necessary for an operator to have to drive his machine on to dangerous slopes to get the spray nozzle close enough to the weeds at the bottom of the slope.The hose should be long enough for the tractor to be parked on easier ground at the top of the slope.

\section{EDITOR'S NOTE}

After delivering the above paper, Mr Crosbie, with the aid of a remote controlled electric model tractor, demonstrated 5 different ways of upsetting a wheeled tractor. They were:

1. A tractor will roll over if sharp turns are made at high speed-even on level fields.

2. A tractor will somersault backward if after it has been stuck in a drain or marshy country, the rear wheels are immobilised by jamming them with logs of wood, etc. The safe way of handling such situations is either to back out or if this is not possible to get towed out by another tractor.

3. A tractor will somersault backward if a heavy load is hitched higher than to the normal drawbar, that is, to the rear axle, seat standard, or to the top jaws of the 3-point linkage.

4. A tractor will somersault backward if it is driven straight up an increasingly steep slope or if it meets near vertical ledges on a moderate slope, for example, sheep or cattle tracks, slip faces, or sheep camps.

5. A tractor will roll over sideways if it is driven across an increasingly steep slope; or if on a steep slope the top rear wheel rides over a bump, stone, or log; or alternatively the bottom rear wheel, drops into a hole or over a ledge. Again on steep slopes tractors will often slide sideways before they roll, but in sliding sideways, the machine passes on to steeper country or over a ledge into an old creek bed, washout, or other obstruction so that the unit rolls over and the driver is killed.

$\mathrm{Mr}$ Crosbie said that there was nothing difficult about tractor safety Simple happenings and neglect of simple precautions had cost numerous operators their lives in the past. All that was required to reduce this tragic toll of life was that simple safety rules be observed and that operators keep alert at all times. Surely it is an easy thing to learn by others' mistakes, far easier than learning the hard way. 